\title{
Rancang Bangun Game Sad Ripu Berbasis Mobile Platform Android
}

\author{
Komang Arta Wibawa, Putu Wira Buana, I Made Agus Dwi Suarjaya \\ Program Studi Teknologi Informasi, Fakultas Teknik, Universitas Udayana \\ Bukit Jimbaran, Bali, Indonesia Telp. (0361) 701806 \\ e-mail: artahace@gmail.com, whbuana@gmail.com, agussuarjaya@it.unud.ac.id
}

\begin{abstract}
Abstrak
Sad Ripu adalah salah satu bagian dari ajaran agama Hindu yang memiliki arti enam musuh di dalam diri manusia. Fakta bahwa beberapa materi pelajaran di Indonesia khususnya pelajaran agama Hindu hanya diajarkan pada satu jenjang pendidikan menjadikan beberapa materi pelajaran terlupakan seiring waktu. Pentingnya makna yang terkandung dalam materi Sad Ripu yaitu mengenai pengendalian diri serta melihat masalah sistem pendidikan terkait penyampaian materi pelajaran mendasari ide tentang pemanfaatan media baru untuk menyampaikan materi Sad Ripu dengan cara yang lebih menarik. Game Sad Ripu dibangun untuk platform mobile Android, bergenre Tactical RPG (Role Playing Game), serta menerapkan sistem pertarungan Player versus Non-Player Character (NPC). Hasil pengujian menunjukkan hasil yang positif terkait penyampaian materi Sad Ripu, dengan total persentase jawaban setuju dan sangat setuju $88.89 \%$ pada aspek cerita, $70.67 \%$ jawaban setuju dan sangat setuju pada aspek grafis, serta $82.32 \%$ jawaban setuju dan sangat setuju pada aspek fungsionalitas.
\end{abstract}

Kata kunci: Game, Android, Al, Sad Ripu, Tactical Game

\begin{abstract}
Sad Ripu is one part of the teachings of Hinduism which means six enemies in humans. The fact that some subject matter in Indonesia especially Hinduism is only taught once makes some subject matter forgotten over time. The important meaning contained in Sad Ripu's material, which is about self-control and seeing the problem of the education system in Indonesia, underlies the idea of using new media to deliver Sad Ripu material in a more interesting way. Sad Ripu Game was built for the Android mobile platform, Tactical RPG (Role Playing Game) genre, and implemented a Player versus Non-Player Character (NPC) battle system. The test results show positive results, with the total percentage of answers agreeing and strongly agree $88.89 \%$ in the aspect of the story, $70.67 \%$ of the answers agree and strongly agree on the graphic aspects, and $82.32 \%$ of the answers agree and strongly agree on aspects of functionality.
\end{abstract}

Keywords: Game, Android, Al, Sad Ripu, Tactical Game

\section{Pendahuluan}

Pulau Bali dikenal sebagai tujuan wisata dengan berbagai kebudayaan yang unik. Bali dikenal sebagai "Pulau Seribu Pura" dengan penduduknya yang mayoritas beragama Hindu. Agama Hindu sebagai salah satu agama yang diakui di Indonesia tentunya masuk dalam kurikulum pendidikan, khususnya di Bali pada tingkat SD, SMP, SMA/SMK sampai Perguruan Tinggi. Pendidikan Agama Hindu yang diajarkan pada setiap tingkat pendidikan tentunya berbeda-beda. Beberapa pelajaran yang diberikan pada tingkat SD tidak diajarkan kembali pada jenjang pendidikan selanjutnya. Fakta bahwa beberapa pelajaran tidak diulang kembali pada jenjang pendidikan selanjutnya menyebabkan materi pelajaran tertentu akan terlupakan seiring waktu, salah satunya adalah materi Sad Ripu pada pelajaran Agama Hindu. Sad Ripu yang dalam ajaran agama Hindu berarti enam musuh di dalam diri manusia merupakan salah satu materi tentang pengendalian diri yang penting untuk dipelajari.

Kemunculan berbagai perangkat elektronik yang semakin canggih seiring dengan perkembangan teknologi menjadi awal dari pemanfaatan media elektronik sebagai media pembelajaran dan pelestarian budaya, salah satunya adalah aplikasi permainan. Pemilihan game sebagai media pembelajaran serta pelestarian budaya dilatarbelakangi oleh fenomena yang terjadi pada masyarakat dalam hal penggunaan perangkat mobile atau smartphone. Fenomena maraknya penggunaan smartphone di masyarakat menjadikan smartphone sebagai 
media yang efektif untuk pembelajaran serta pelestarian budaya dengan cara menyisipkan pesan-pesan edukasi serta unsur-unsur budaya di dalam sebuah aplikasi, khususnya game. Industri game di sisi lain pada saat ini merupakan salah satu industri yang memiliki potensi menjadi bidang yang perlu diperhatikan di Indonesia, ditunjukkan dengan pertumbuhan industri game di Indonesia yang menempati posisi kedua setelah Thailand pada wilayan Asia Pasifik [1].

Game yang pernah diteliti terkait pembelajaran dan pelestarian budaya Bali yaitu game sebagai media pelestarian cerita rakyat bali, media pelestarian tari Bali, game sebagai media pengenalan tradisi pada daerah Bali, aplikasi Augmented Reality (AR) untuk memperkenalkan pura Tanah Lot dan game sebagai media pelestarian Wayang Bali. Penelitian "Pemanfaatan Media Game I Gerantang untuk Melestarikan Cerita Rakyat Bali" oleh Pande Nengah Purnawan membahas mengenai penggunaan media game sebagai media pelestarian cerita rakyat bali yaitu cerita "I Cupak lan I Gerantang" [2]. Penelitian yang berjudul "Application of Balinese Dance Using Augmented Reality on Android" merupakan penelitian yang menggunakan media Virtual Reality untuk pelestarian kearifan lokal di Bali yaitu tari Bali [3]. Penelitian "Pengenalan Tradisi Budaya Bali melalui Aplikasi Game Explore Bali Berbasis Android" oleh Dewa Putu Andre Sanjaya membahas mengenai penggunaan game untuk mengenalkan tradisi yang ada pada setiap kabupaten di Bali [4]. Penelitian yang berjudul "Augmented reality mobile application of Balinese Hindu temples: DewataAR" oleh Adi Ferliyanto Waruwu membahas mengenai penggunaan Virtual Reality untuk pengenalan pura Tanah Lot di Bali [5]. Penelitian "Game "Wayang Fighter" pada Platform Android menggunakan Algoritma Basic Probability" membahas mengenai game sebagai media pelestarian kearifan lokal di Bali dalam bentuk game pertarungan [6]. Penelitian-penelitian yang telah disebutkan sebelumnya merupakan beberapa penelitian terkait dengan pemanfaatan media game sebagai media pelestarian kearifan lokal di Bali.

Game pada umumnya dikategorikan ke dalam satu atau lebih kategori atau disebut genre. Game dengan genre tactical RPG (Role Playing Game) merupakan salah satu genre yang digemari oleh kalangan umum. Salah satu game dengan genre tactical RPG yaitu "Final Fantasy Tactics : War of The Lions" yang diproduksi pada tahun 1997 oleh Square dengan platform konsol Playstation. Berkaitan dengan game bergenre tactical, penerapan Artificial Intellegince (Al) merupakan hal yang esensial. Al yang diterapkan dalam game salah satunya adalah pathfinding. Pathfinding umumnya digunakan dalam game RPG dan real-time stragegy yang memiliki karakter yang harus bergerak dari satu destinasi ke destinasi yang ditentukan [7].

Metode pathfinding telah diteliti pada beberapa penelitian salah satunya yaitu penelitian tentang Navigation Mesh pada Unity 3D, serta penelitian terkait perbandingan algoritmaalgoritma pathfinding yang diterapkan pada game maze runner. Penelitian berjudul "Research and Application of Path-finding Algorithm Based on Unity 3D" oleh Zhang He [8] membahas mengenai dua buah algoritma pathfinding yaitu Navigation Mesh (Navmesh) dan algoritma A* yang diimplementasikan pada engine Unity3D. Penelitian yang berjudul "Comparative Analysis of Pathfinding Algorithms A *, Dijkstra, and BFS on Maze Runner Game" membahas mengenai perbandingan 3 jenis algoritma pathfinding yang diterapkan pada game maze runner [9]. Penelitian-penelitian yang telah disebutkan sebelumnya merupakan beberapa penelitian yang terkait dengan penggunaan AI dalam game yang meliputi pengambilan keputusan serta metode pathfinding.

Pentingnya makna yang terkandung dalam materi Sad Ripu serta melihat sistem pendidikan di Indonesia terkait penyampaian materi pelajaran di sekolah mendasari ide Game Sad Ripu sebagai media untuk menyampaikan kembali materi Sad Ripu. Game Sad Ripu dibangun untuk platform mobile Android, bergenre Tactical RPG (Role Playing Game), serta menerapkan sistem pertarungan Player versus Non-Player Character (NPC). Game Sad Ripu dibuat dengan menggabungkan beberapa aspek dari penelitian-penelitian sebelumnya yaitu penggunaan game sebagai media pembelajaran dan pelestarian budaya lokal, serta penerapan Al (Artificial Intelligence) pada NPC di dalam game.

\section{Metodologi Penelitian}

Penelitian Rancang Bangun Game Sad Ripu Berbasis Mobile Platform Android dilakukan dalam 5 tahapan yang ditunjukkan pada Gambar 1. 


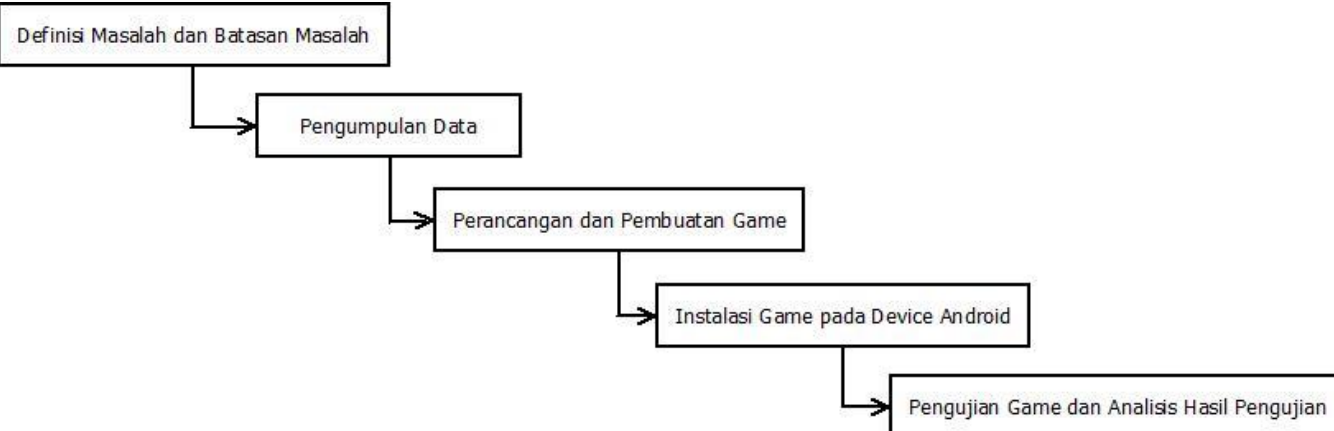

Gambar 1. Alur Penelitian Game Sad Ripu

Gambar 1 merupakan alur penelitian Game Sad Ripu Berbasis Mobile Platform Android. Alur penelitian dimulai dari pendefinisian masalah dan batasan masalah, pengumpulan data yang berhubungan dengan perancangan dan pembuatan game, proses perancangan dan pembuatan game pada game engine Unity, instalasi game pada device Android, dan pengujian game pada sejumlah user serta pembuatan analisis hasil pengujian.

Pengujian Game Sad Ripu dilakukan menggunakan kuesioner sebagai media pengumpulan data yang melibatkan 30 orang berumur 15 tahun keatas. Aspek-aspek yang dinilai terdiri dari aspek cerita, aspek grafis, dan aspek fungsionalitas. Penetapan skor dalam kuesioner menggunakan skala Likert, yaitu Sangat Setuju (SS), Setuju (S), Cukup (C), Tidak Setuju (TS), dan Sangat Tidak Setuju (STS).

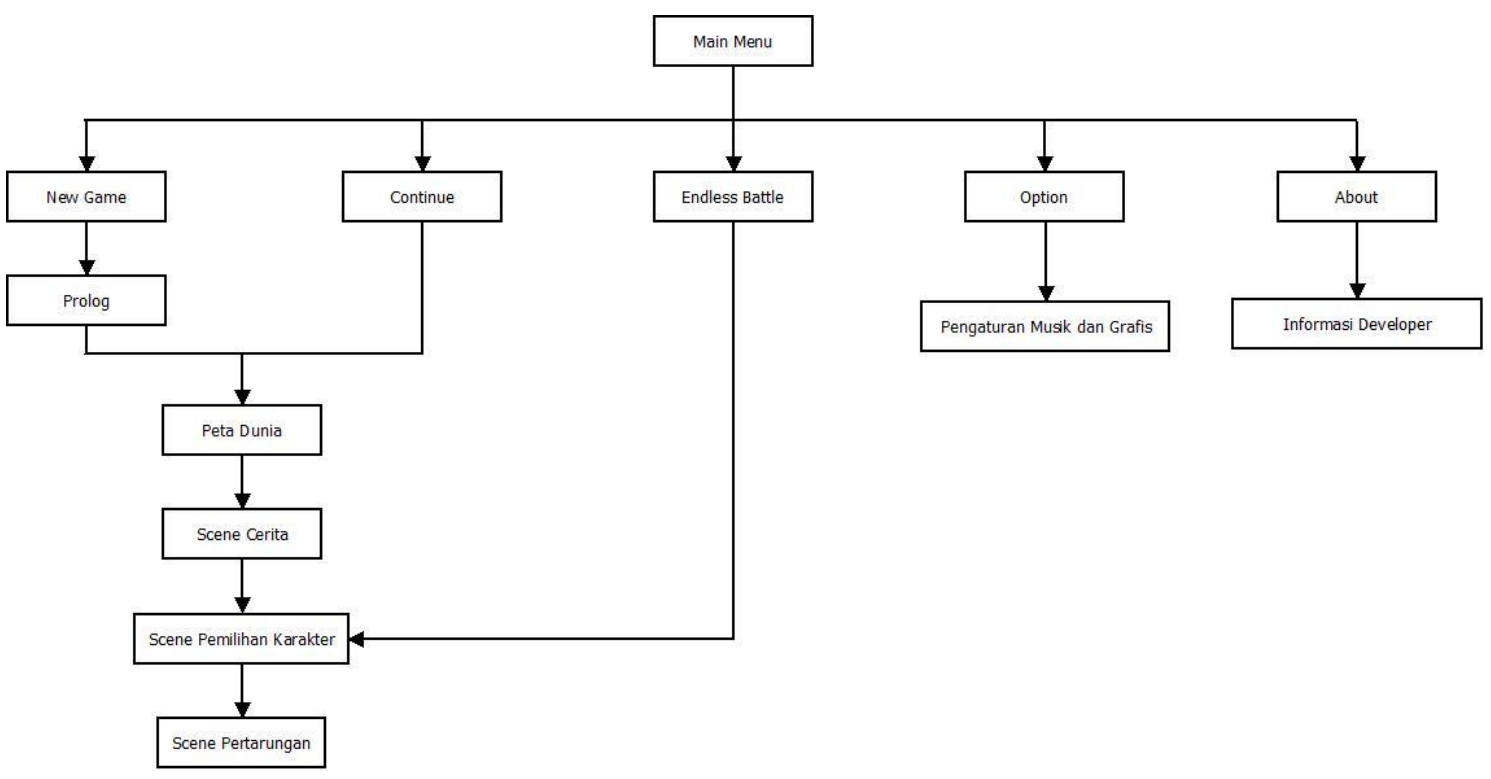

Gambar 2. Gambaran Umum Game Sad Ripu

Gambar 2 adalah gambaran umum dari Game Sad Ripu. Game Sad Ripu memiliki 5 menu yang dapat dipilih di awal game, yaitu new game, continue, endless battle, option, dan about. Menu option menampilkan sebuah pop-up window yang berisikan pengaturan grafis dan audio, menu about menampilkan informasi dari developer, menu new game dan continue mengarah ke jalan cerita utama Game Sad Ripu yang dimulai dari scene prolog, scene peta dunia, scene cerita, scene pemilihan karakter dan scene pertarungan. Menu Endless Battle mengarahkan user ke dalam pertarungan yang tidak berkaitan dengan jalan cerita Game Sad Ripu. 


\section{Kajian Pustaka}

\subsection{Sad Ripu}

Sad Ripu berasal dari kata "sad" yang berarti enam dan "ripu" yang berarti musuh. Sad Ripu adalah enam musuh di dalam diri manusia yang perlu dikendalikan [10]. Sad Ripu terdiri dari 6 bagian antara lain:

1. Kama yaitu hawa nafsu negatif yang tidak terkendalikan.

2. Lobha yaitu kelobaan (ketamakan), yaitu perasaan ingin selalu mendapatkan lebih.

3. Krodha yaitu kemarahan yang melampaui batas (tidak terkendalikan).

4. Mada yaitu kemabukan yang membawa kegelapan pikiran.

5. Moha yaitu kebingungan atau kurang mampu berkonsentrasi yang mengakibatkan individu tidak dapat menyelesaikan tugas dengan sempurna.

6. Matsarya yaitu iri hati atau rasa dengki yang menyebabkan permusuhan.

\subsection{Android}

Android adalah sebuah susunan perangkat lunak untuk perangkat seluler yang mencakup sistem operasi, middleware, serta aplikasi. Sistem operasi Android didasari oleh kernel Linux dengan versi yang dimodifikasi. Android Inc dibentuk di Palo Alto, California United States pada Oktober 2003 oleh Andy Rubin, Rich Miner, Nick Sears, dan Chris White. Android Inc kemudian diakuisisi oleh Google pada tahun 2005 [11].

\subsection{Navigation Mesh}

Navigation Mesh atau Navmesh adalah metode untuk merepresentasikan dunia game menggunakan polygon [12]. Navigation Mesh merupakan konsep pathfinding yang populer digunakan dalam game 3D karena environtment dalam game 3D umumnya terbuat dari struktur polygon [13].

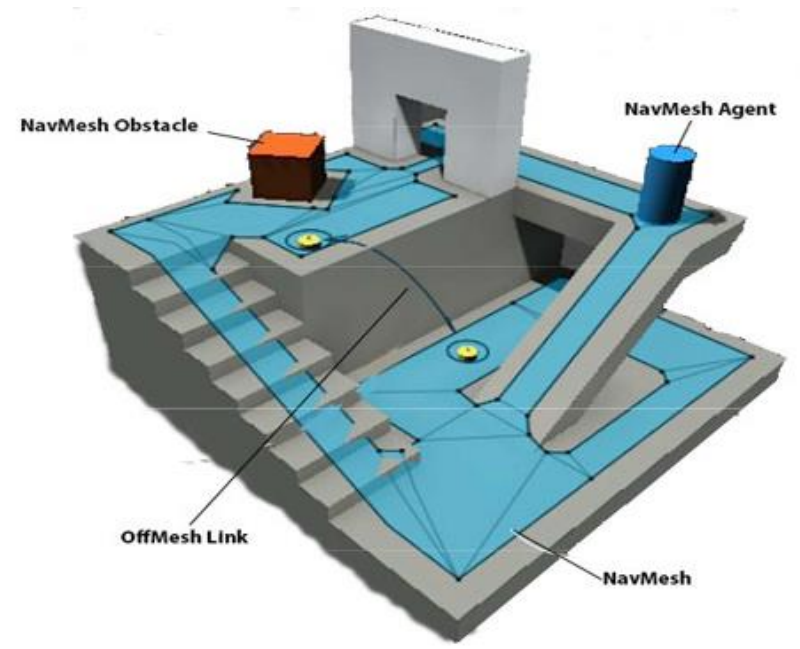

Gambar 3. Komponen Navigation Mesh Unity

Gambar 3 menunjukkan beberapa komponen dalam Navigation Mesh di game engine Unity, yaitu:

1. Navmesh yaitu struktur polygon yang menggambarkan permukaan yang dapat dilalui (walkable) dalam game,

2. Navmesh Agent yaitu sebuah komponen yang dapat bergerak ke destinasi tujuan pada permukaan Navmesh,

3. Navmesh Obstacle, yaitu sebuah komponen objek yang harus dihindari oleh Navmesh Agent,

4. OffMeshLink, adalah sebuah komponen yang menghubungkan titik koneksi yang tidak dapat direpresentasikan saat menggunakan permukaan walkable pada Navmesh. 


\section{Hasil dan Pembahasan}

\subsection{Hasil Perancangan Game Sad Ripu}

Hasil perancangan dari Game Sad Ripu yang ditampilkan meliputi tampilan scene main menu, scene cerita, scene world map, scene pemilihan karakter serta scene pertarungan.

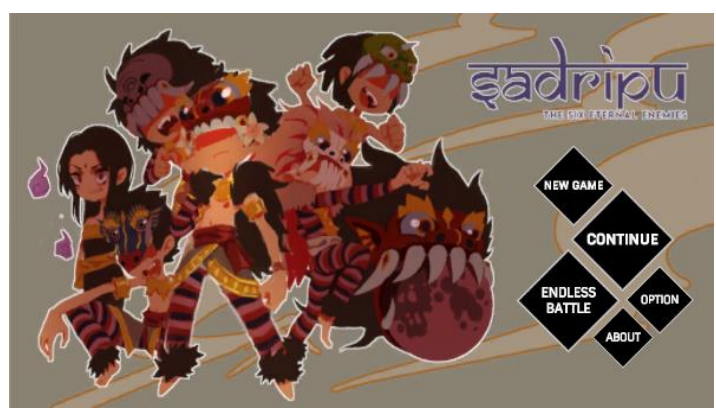

(a)

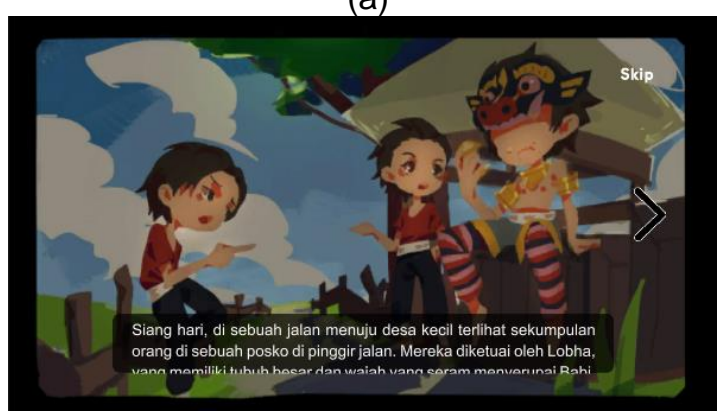

(c)

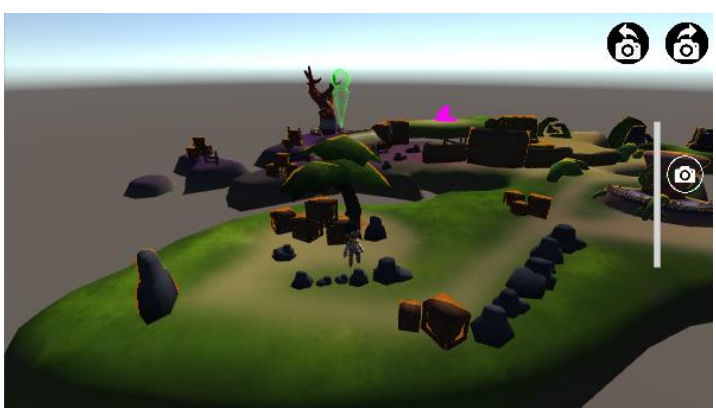

(b)

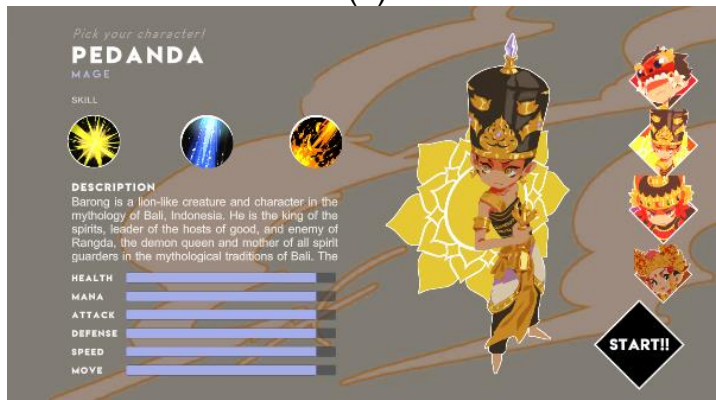

(d)

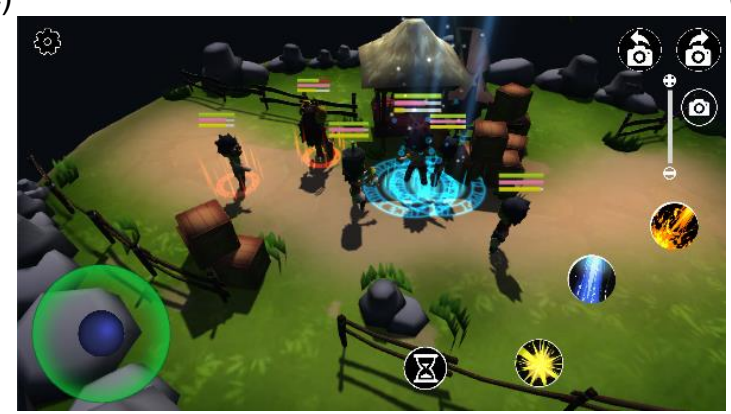

(e)

Gambar 4. Tampilan Hasil Perancangan Scene : (a) Scene Main Menu; (b) Scene World Map; (c) Scene Cerita; (d) Scene Pemilihan Karakter; (e) Scene Pertarungan

Gambar 4 bagian (a) adalah tampilan dari scene main menu pada Game Sad Ripu. Main Menu terdiri dari 5 buah menu, yaitu menu New Game, Continue, Endless Battle, Option, dan About. Gambar 4 bagian (b) adalah tampilan scene world map. Scene world map merepresentasikan alur cerita dari Game Sad Ripu dalam bentuk stage. Scene world map terdiri dari sejumlah stage yang meliputi stage boss dan mini stage, karakter utama, serta beberapa tombol navigasi kamera. Pergerakan karakter pada scene world map menggunakan sistem click-to-move, yaitu user harus mengklik salah satu stage untuk bergerak ke arah tertentu. Gambar 4 bagian (c) adalah tampilan scene cerita yang menampilkan kisah-kisah karakter Sad Ripu beserta cerita prolog dan ending. Scene cerita terdiri dari beberapa gambar, dan naskah cerita, serta beberapa tombol. Gambar 4 bagian (d) merupakan tampilan scene pemilihan karakter yang terdiri dari beberapa komponen yang menampilkan informasi dari karakter yang dipilih berupa nama, role, skill, deskripsi, status, dan gambar karakter. Karakter yang dapat dipilih berjumlah 3 unit karakter dari total 4 unit karakter yang disediakan. Gambar 4 bagian (e) merupakan tampilan dari scene pertarungan. Scene pertarungan terdiri dari beberapa komponen yaitu karakter player, karakter NPC, objek environtment, kontrol joystick pergerakan dan skill, kontrol kamera, serta satu tombol untuk menampilkan menu surrender. Karakter NPC yang ada di dalam scene pertarungan mengimplementasikan Al dalam hal 
pergerakan dan pengambilan keputusan, seperti memilih skill, destinasi gerakan, dan memilih target. Sistem pertarungan menggunakan sistem Active Time Battle yang menentukan giliran karakter. Skill dari setiap karakter terdapat 3 buah skill dengan tipe skill yang telah ditentukan. Tipe dari skill dibagi menjadi 3 yaitu skill tipe menyerang, skill tipe support, dan skill tipe buff/debuff.

\subsection{Hasil Perancangan Al pada NPC}

Al yang diterapkan pada NPC di dalam game meliputi penggunaan Navigation Mesh (Navmesh) pada game engine Unity dan pola pergerakan NPC dalam game.

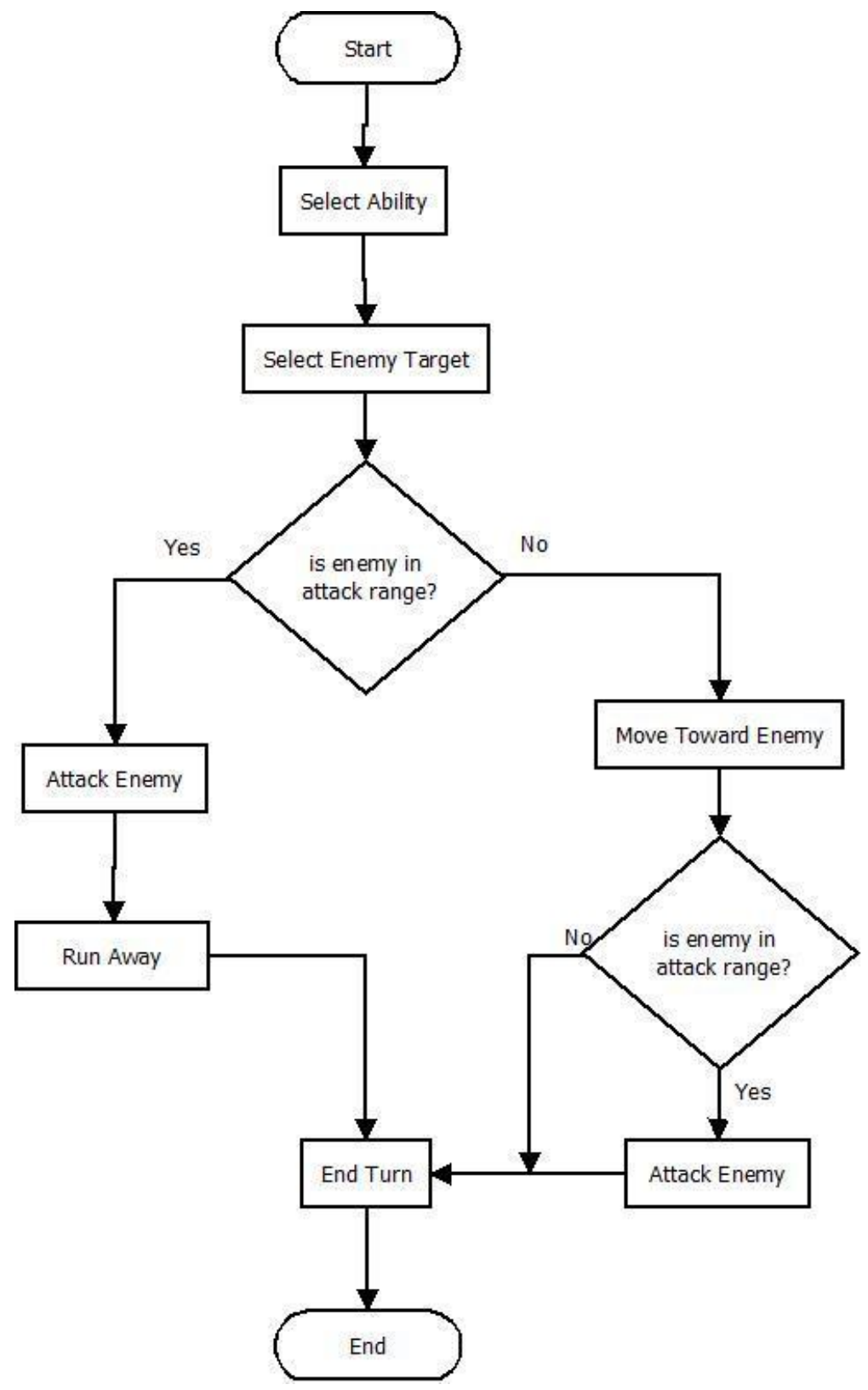

Gambar 5. Flowchat Pengambilan Keputusan NPC

Gambar 5 menunjukkan prosedur pengambilan keputusan NPC dalam Game Sad Ripu. Keputusan NPC ditentukan dengan metode heuristik, dimana suatu keputusan ditentukan ketika kondisi tertentu terpenuhi. Pengambilan keputusan pada NPC dibagi menjadi 3 jenis keputusan yaitu pemilihan ability, pemilihan target, dan pemilihan aksi. Keputusan pemilihan ability ditentukan berdasarkan kriteria damage terbesar, serta mana cost terkecil. Keputusan 
pemilihan target ditentukan berdasarkan jarak target terdekat dan HP target terkecil. Keputusan aksi yang berupa pergerakan dan penggunaan ability terhadap target ditentukan berdasarkan jarak serang NPC dengan target. NPC bergerak menuju arah target apabila target berada di luar jarak serang dan menyerang target apabila target sudah berada di dalam jarak serang NPC, sebaliknya apabila target berada di dalam jarak serang maka NPC akan menyerang target dan kemudian bergerak menjauh dari target.

Navigation mesh atau NavMesh dibentuk dengan menentukan objek-objek walkable dan non-walkable pada environtment 3D dalam game, menentukan informasi Navmesh Agent, serta melakukan bake terhadap environtment 3D.

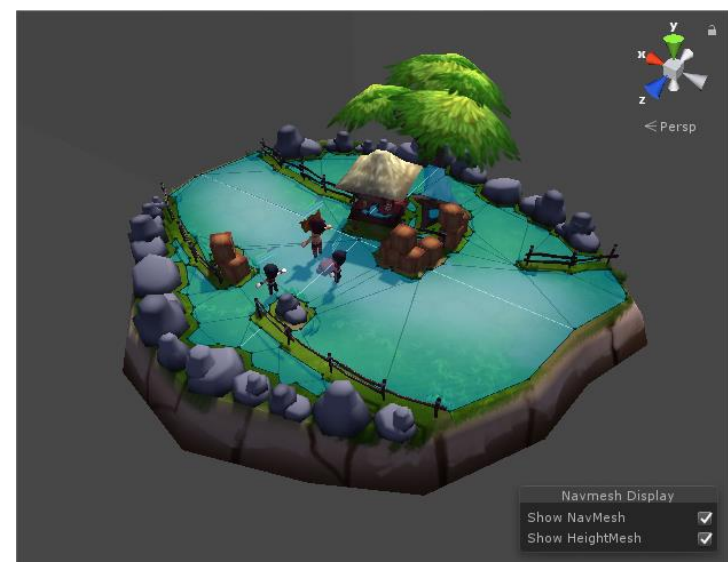

(a)

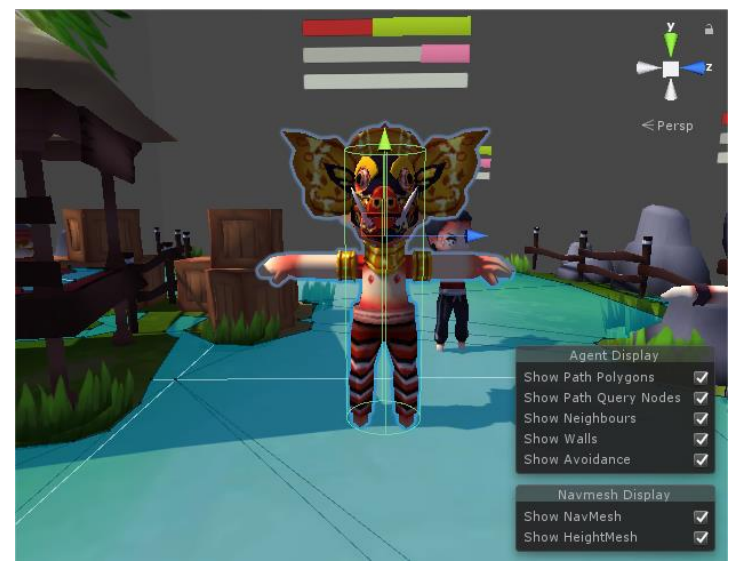

(b)

Gambar 6. Navigation Mesh pada Game Sad Ripu: (a) Navmesh pada Environtment 3D; (b) Navmesh Agent pada Karakter NPC

Gambar 6 merupakan tampilan hasil bake Navmesh yang dilakukan pada salah satu stage Game Sad Ripu. Gambar 6 (a) merupakan hasil bake Navmesh pada sebuah environtment 3D dalam Game Sad Ripu yang ditunjukkan dengan polygon berwarna biru pada permukaan objek. Gambar 6 (b) merupakan komponen Navmesh Agent pada sebuah karakter NPC yang berbentuk silinder berwarna hijau pada karakter.

Pergerakan karakter dibedakan menjadi 2 jenis, yaitu pergerakan mendekati target dan pergerakan menjauhi target. Pergerakan dari karakter NPC dilakukan dengan menentukan sebuah titik destinasi NavMesh Agent, sehingga NavMesh Agent secara otomatis akan bergerak menuju destinasi dan menghindari obstacle pada environtment.

Titik destinasi dari NavMesh Agent ditentukan berdasarkan jenis pergerakan karakter. Titik destinasi untuk jenis pergerakan mendekati target ditentukan dengan menggunakan posisi dari target tersebut. Titik destinasi untuk jenis pergerakan menjauhi target ditentukan dengan memilih titik acak yang memiliki jarak lebih besar dari jarak antara posisi target dengan posisi NPC saat ini.
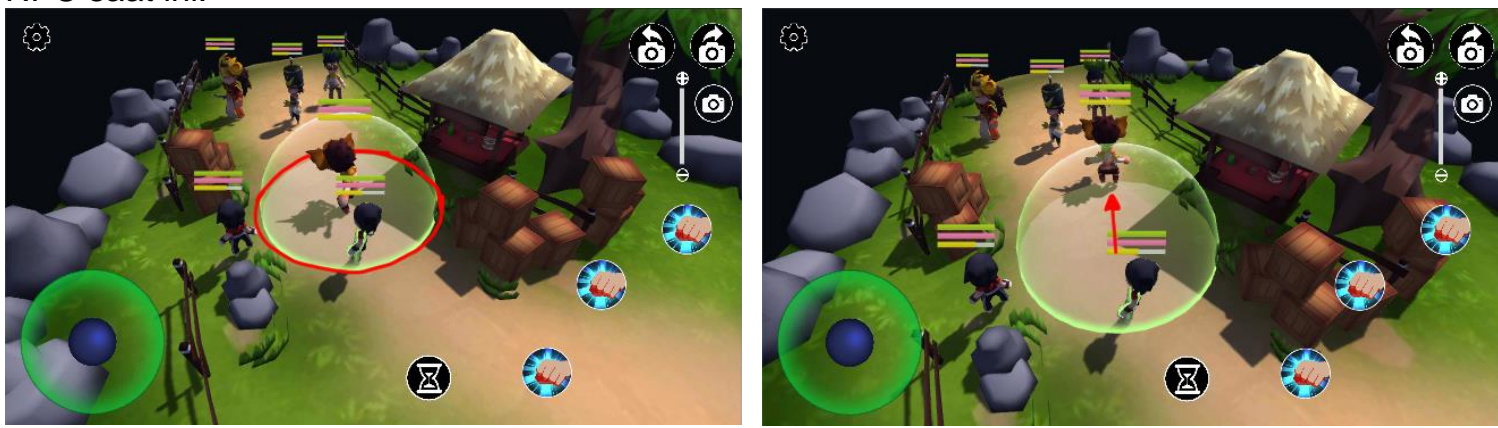

(a) 

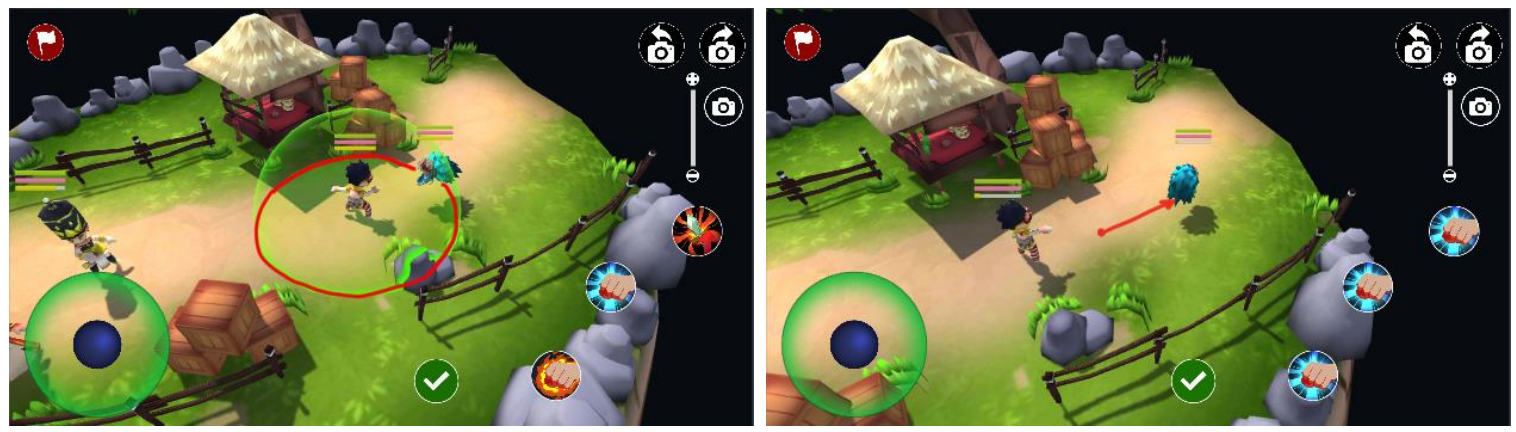

(b)

Gambar 7. Pergerakan NPC pada Game Sad Ripu: (a) Pergerakan Mendekati Player; (b)

Pergerakan Menjauhi Player

Gambar 7 menunjukkan dua jenis pergerakan NPC di dalam Game Sad Ripu. Gambar 7 bagian (a) merupakan jenis pergerakan NPC yang mendekati karakter player. Gambar 7 bagian (b) merupakan jenis pergerakan NPC yang menjauhi player.

\subsection{Hasil Pengujian Game Sad Ripu}

Pengujian Game Sad Ripu dilakukan dengan menggunakan kuesioner sebagai media pengumpulan data. Responden kuesioner dari pengujian Game Sad Ripu berjumlah sebanyak 30 orang di Bali yang berumur 15 tahun ke atas. Hasil pengujian yang dilakukan pada beberapa aspek adalah sebagai berikut.

\section{Aspek Cerita}

Penilaian dari aspek cerita dinilai dari kesesuaian antara kisah cerita karakter Sad Ripu pada Game Sad Ripu dengan bagian-bagian Sad Ripu dalam ajaran Agama Hindu. Hasil pengujian pada aspek cerita ditunjukkan pada Tabel 1.

Tabel 1. Hasil Pengujian Aspek Cerita

\begin{tabular}{cc}
\hline Kriteria & Persentase \\
\hline Sangat Setuju & $43.89 \%$ \\
\hline Setuju & $45 \%$ \\
\hline Cukup & $11.11 \%$ \\
\hline Tidak Setuju & $0 \%$ \\
\hline Sangat Tidak Setuju & $0 \%$ \\
\hline
\end{tabular}

Berdasarkan Tabel 1, jawaban setuju memiliki persentase jawaban yang paling besar yaitu sebesar $58.89 \%$ dengan jumlah responden sebanyak 30 orang. Jawaban setuju mengindikasikan bahwa kisah cerita dari karakter Sad Ripu sudah sesuai atau berhasil merepresentasikan bagian-bagian Sad Ripu dalam ajaran Agama Hindu.

\section{Aspek Grafis}

Penilaian dari aspek grafis dinilai dari kesesuaian desain karakter dengan bagianbagian Sad Ripu, pembuatan desain karakter yang bernuansa Bali, desain environtment yang memberikan nuansa Bali, pemilihan warna karakter dan environtment yang user-friendly, serta layout dan pemilihan warna UI yang user-friendly.

Tabel 2. Hasil Pengujian Aspek Grafis

\begin{tabular}{cc}
\hline Kriteria & Persentase \\
\hline Sangat Setuju & $26.00 \%$ \\
\hline Setuju & $44.67 \%$ \\
\hline Cukup & $28.67 \%$ \\
\hline Tidak Setuju & $0.67 \%$ \\
\hline Sangat Tidak Setuju & $0 \%$ \\
\hline
\end{tabular}


Berdasarkan Tabel 2, jawaban setuju memiliki persentase jawaban yang paling besar yaitu sebesar $66 \%$ dengan jumlah responden sebanyak 30 . Jawaban setuju mengindikasikan bahwa kisah cerita dari karakter Sad Ripu sudah sesuai atau berhasil merepresentasikan bagian-bagian Sad Ripu dalam ajaran Agama Hindu.

\section{Aspek Fungsionalitas}

Penilaian aspek fungsionalitas dibagi menjadi fungsionalitas scene main menu, fungsionalitas scene world map, fungsionalitas scene cerita, fungsionalitas scene pemilihan karakter, fungsionalitas scene pertarungan, dan fungsionalitas AI NPC. Aspek fungsionalitas dinilai dari fitur-fitur yang ada dan sudah berjalan pada sub aspek tertentu.

Tabel 3. Hasil Pengujian Fungsionalitas Scene Main Menu

\begin{tabular}{cc}
\hline Kriteria & Persentase \\
\hline Sangat Setuju & $32.67 \%$ \\
\hline Setuju & $42 \%$ \\
\hline Cukup & $22 \%$ \\
\hline Tidak Setuju & $3.33 \%$ \\
\hline Sangat Tidak Setuju & $0 \%$ \\
\hline
\end{tabular}

Tabel 4. Hasil Pengujian Fungsionalitas Scene World Map

\begin{tabular}{cc}
\hline Kriteria & Persentase \\
\hline Sangat Setuju & $36.67 \%$ \\
\hline Setuju & $49.17 \%$ \\
\hline Cukup & $14.17 \%$ \\
\hline Tidak Setuju & $0 \%$ \\
\hline Sangat Tidak Setuju & $0 \%$ \\
\hline
\end{tabular}

Tabel 5. Hasil Pengujian Fungsionalitas Scene Cerita

\begin{tabular}{cc}
\hline Kriteria & Persentase \\
\hline Sangat Setuju & $46.67 \%$ \\
\hline Setuju & $41.11 \%$ \\
\hline Cukup & $12.22 \%$ \\
\hline Tidak Setuju & $0 \%$ \\
\hline Sangat Tidak Setuju & $0 \%$ \\
\hline
\end{tabular}

Tabel 6. Hasil Pengujian Fungsionalitas Scene Pemilihan Karakter

\begin{tabular}{cc}
\hline Kriteria & Persentase \\
\hline Sangat Setuju & $54.00 \%$ \\
\hline Setuju & $35.33 \%$ \\
\hline Cukup & $9.33 \%$ \\
\hline Tidak Setuju & $1.33 \%$ \\
\hline Sangat Tidak Setuju & $0 \%$ \\
\hline
\end{tabular}

Tabel 7. Hasil Pengujian Fungsionalitas Scene Pertarungan

\begin{tabular}{cc}
\hline Kriteria & Persentase \\
\hline Sangat Setuju & $36.67 \%$ \\
\hline Setuju & $47.14 \%$ \\
\hline Cukup & $15.71 \%$ \\
\hline Tidak Setuju & $0.48 \%$ \\
\hline Sangat Tidak Setuju & $0 \%$ \\
\hline
\end{tabular}

Tabel 8. Hasil Pengujian Fungsionalitas AI NPC

\begin{tabular}{cc}
\hline Kriteria & Persentase \\
\hline Sangat Setuju & $31.67 \%$ \\
\hline Setuju & $40.83 \%$ \\
\hline Cukup & $27.5 \%$ \\
\hline
\end{tabular}




\begin{tabular}{cc}
\hline Tidak Setuju & $0.48 \%$ \\
\hline Sangat Tidak Setuju & $0 \%$ \\
\hline
\end{tabular}

Tabel 1 hingga Tabel 8 merupakan hasil pengujian yang dilakukan terhadap aspek fungsionalitas, mulai dari scene main menu, scene, scene cerita, scene pemilihan karakter, scene pertarungan serta fungsionalitas AI NPC. Hasil pengujian menunjukkan jawaban positif (jawaban sangat setuju dan setuju) terkait fungsionalitas dari Game Sad Ripu, dengan persentase sebesar $74.67 \%$ pada scene main menu, $85.53 \%$ pada scene world map, $87.78 \%$ pada scene cerita, 89.33 pada scene pemilihan karakter, $83.81 \%$ pada scene pertarungan, serta $72.5 \%$ untuk fungsionalitas AI NPC. Hasil pengujian dari aspek fungsionalitas dapat diambil dari rata-rata hasil pengujian sub aspek di atas, ditunjukkan pada Tabel 9.

\begin{tabular}{cc} 
Tabel 9. Hasil Pengujian Aspek Fungsionalitas \\
\hline Kriteria & Persentase \\
\hline Sangat Setuju & $39.72 \%$ \\
\hline Setuju & $42.6 \%$ \\
\hline Cukup & $16.82 \%$ \\
\hline Tidak Setuju & $0.86 \%$ \\
\hline Sangat Tidak Setuju & $0 \%$ \\
\hline
\end{tabular}

Tabel 9 merupakan hasil rata-rata dari semua fungsionalitas dalam Game Sad Ripu, yang menunjukkan persentase jawaban positif sebesar $82.32 \%$. Persentase jawaban positif terhadap semua fungsionalitas pada Game Sad Ripu menunjukkan bahwa fitur-fitur di dalam Game Sad Ripu telah berjalan sebagaimana mestinya. Hasil pengujian dari ketiga aspek yang disebutkan sebelumnya dapat digambarkan dalam bentuk diagram yang ditunjukkan pada Gambar 8.

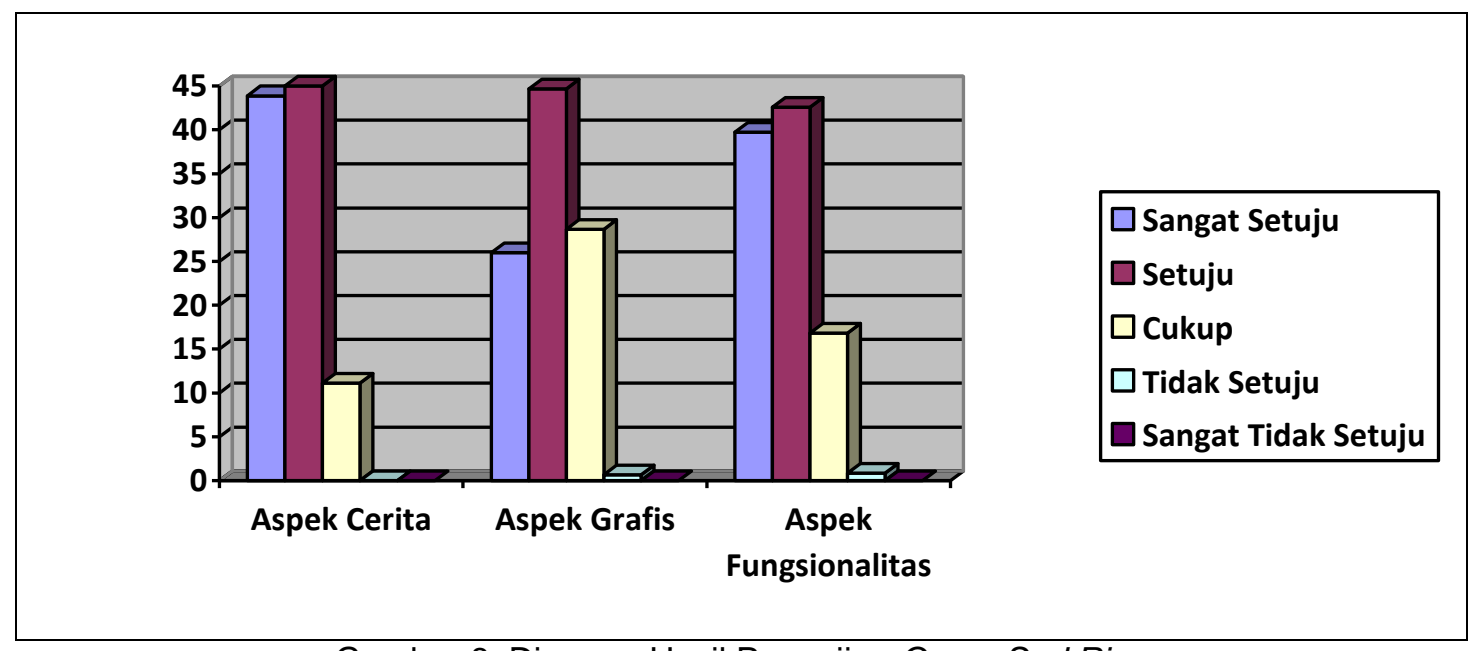

Gambar 8. Diagram Hasil Pengujian Game Sad Ripu

Gambar 8 menunjukkan diagram hasil pengujian Game Sad Ripu terhadap aspek cerita, grafis dan fungsionalitas. Data pada diagram di atas menujukkan respon positif yang mana merupakan gabungan dari jawaban sangat setuju dan jawaban setuju memiliki nilai paling besar pada ketiga aspek pengujian.

\section{Kesimpulan}

Game Sad Ripu dibangun dengan genre Tactical RPG yang menerapkan sistem pertarungan Player VS Computer (NPC Al). Game Sad Ripu dibangun dengan target platform mobile Android. Game Sad Ripu terdiri dari 5 buah scene utama yaitu scene main menu, scene world map, scene cerita, scene pemilihan karakter serta scene pertarungan. Bagian-bagian Sad Ripu di dalam Game Sad Ripu direpresentasikan sebagai karakter-karakter dengan kisahnya masing-masing, yang mana merupakan karakter yang harus dikalahkan pemain di dalam game. 
Pengujian dilakukan pada 3 aspek yaitu aspek cerita, grafis dan fungsionalitas. Hasil pengujian menunjukkan hasil yang positif, dengan persentase jawaban setuju dan sangat setuju sebesar 88.89\% dalam aspek cerita, yang menunjukkan kisah-kisah karakter Sad Ripu pada game berhasil merepresentasikan sifat-sifat bagian Sad Ripu dalam ajaran Agama Hindu, 70.67\% jawaban setuju dan sangat setuju dalam aspek grafis yang menunjukkan komponen UI bersifat user-friendly serta desain karakter pada game memiliki nuansa Bali, dan $82.32 \%$ jawaban setuju dan sangat setuju dalam aspek fungsional yang menunjukkan fitur-fitur di dalam game berjalan sesuai fungsinya.

\section{Daftar Pustaka}

[1] I. F. Maddarangan, N. V, and B. M. Wibawa, "Analisis Deskriptif Pemain Online Game Pada Game Defense of the Ancients 2 (Dota 2)," Jurnal Teknik ITS, vol. 7, no. 1. 2018.

[2] P. N. Purnawan, A. A. K. Agung, C. Wiranatha, and I. A. D. Suarjaya, "Pemanfaatan Media Game I Gerantang untuk Melestarikan Cerita Rakyat Bali," Jurnal IImiah Merpati, vol. Vol. 6, no. 2. pp. 127-135, 2018.

[3] N. P. S. Franza, A. A. K. Oka Sudana, and K. S. Wibawa, "Application of basic Balinese dance using augmented reality on android," Journal of Theoretical and Applied Information Technology, vol. 90, no. 1. pp. 61-66, 2016.

[4] D. P. A. Sanjaya, I. K. A. Purnawan, and N. K. D. Rusjayanthi, "Pengenalan Tradisi Budaya Bali melalui Aplikasi Game Explore Bali Berbasis Android," Lontar Komputer: Jurnal IImiah Teknologi Informasi, vol. 7, no. 3, p. 162, 2016.

[5] A. F. Waruwu, I. P. Agung Bayupati, and I. K. Gede Darma Putra, "Augmented Reality Mobile Application of Balinese Hindu Temples: DewataAR," International Journal of Computer Network and Information Security, vol. 7, no. 2. pp. 59-66, 2015.

[6] N. A. Muliawan, A. A. K. A. C. Wiranatha, and K. S. Wibawa, "Game 'Wayang Fighter' pada Platform Android menggunakan Algoritma Basic Probability," Lontar Komputer: Jurnal IImiah Teknologi Informasi, vol. 6, no. 3, p. 192, 2015.

[7] N. H. Barnouti, S. S. M. Al-Dabbagh, and M. A. Sahib Naser, "Pathfinding in Strategy Games and Maze Solving Using $A^{*}$ Search Algorithm," Journal of Computer and Communications, vol. 04, no. 11. pp. 15-25, 2016.

[8] Z. He, M. Shi, and C. Li, "Research and application of path-finding algorithm based on unity 3D," 2016 IEEE/ACIS 15th International Conference on Computer and Information Science, ICIS 2016 - Proceedings. 2016.

[9] S. D. Handy Permana, K. B. Yogha Bintoro, B. Arifitama, and A. Syahputra, "Comparative Analysis of Pathfinding Algorithms A *, Dijkstra, and BFS on Maze Runner Game," IJISTECH (International Journal Of Information System \& Technology), vol. 1, no. 2. p. 1, 2018.

[10] N. W. Sumarni and S. H. Raharjo, Pendidikan Agama Hindu dan Budi Pekerti. Pusat Kurikulum dan Perbukuan, Balitbang, Kemendikbud, 2015.

[11] M. Bazard and S. Bhardwaj, "Overview on Android - The New Mobile Operating System," International Journal of Science, Technology and Management, vol. 2, no. 1, pp. 25-34, 2011.

[12] X. Cui and H. Shi, "An Overview of Pathfinding in Navigation Mesh," IJCSNS International Journal of Computer Science and Network Security, vol. 12, no. 12, pp. 4851, 2012.

[13] M. Zikky, "Review of $A^{*}$ (A Star) Navigation Mesh Pathfinding as the Alternative of Artificial Intelligent for Ghosts Agent on the Pacman Game," EMITTER International Journal of Engineering Technology, vol. 4, no. 1, pp. 141-149, 2016. 